\title{
Gonadotropin-releasing hormone agonists reduce the migratory and the invasive behavior of androgen-independent prostate cancer cells by interfering with the activity of IGF-I
}

\author{
MARINA MONTAGNANI MARELLI ${ }^{1}$, ROBERTA M. MORETTI ${ }^{1}$, \\ STEFANIA MAI ${ }^{1}$, PATRIZIA PROCACCI ${ }^{2}$ and PATRIZIA LIMONTA ${ }^{1}$ \\ ${ }^{1}$ Institute of Endocrinology, Center for Endocrinological Oncology; ${ }^{2}$ Institute of Histology, \\ Embryology and Neurocytology, University of Milano, Milano, Italy
}

Received May 15, 2006; Accepted July 26, 2006

\begin{abstract}
Androgen-independent prostate carcinoma is characterized by a high proliferation rate and by a strong metastatic behavior. We have previously shown that GnRH agonists exert a direct and specific inhibitory action on the proliferation of androgen-independent prostate cancer cells (DU 145). These compounds mainly act by interfering with the mitogenic activity of growth factors, such as the insulin-like growth factor-I (IGF-I). The present experiments were performed to clarify whether GnRH agonists might also affect the migratory and the invasive behavior of androgenindependent prostate cancer cells and to define their mechanism of action. First we showed that the GnRH agonist Leuprolide reduces the migration of DU 145 cells towards a chemoattractant and their ability to invade a reconstituted basement membrane. Experiments were then performed to clarify whether the GnRH agonist might act by interfering with the pro-metastatic activity of IGF-I. We found that, in androgen-independent prostate cancer cells, Leuprolide: a) interferes with the IGF-I system (receptor protein expression and tyrosine-phosphorylation); b) abrogates the IGF-I-induced phosphorylation of Akt (a kinase previously shown by us to mediate the pro-metastatic activity of IGF-I in prostate cancer cells); c) counteracts the migration and the invasive activity of the cells stimulated by IGF-I; d) abolishes the effects of IGF-I on cell morphology, on actin cytoskeleton organization and on $\alpha v B 3$ integrin expression/cellular localization. These
\end{abstract}

Correspondence to: Dr Patrizia Limonta, Center for Endocrinological Oncology, Institute of Endocrinology, University of Milano, Via Balzaretti 9, 20133 Milano, Italy

E-mail: patrizia.limonta@unimi.it

Key words: prostate cancer, gonadotropin-releasing hormone, insulin-like growth factor-I, migration, invasion data indicate that GnRH agonists, in addition to their well known antiproliferative effect, can also exert a significant inhibitory activity on the migratory and invasive behavior of androgen-independent prostate cancer cells, expressing the $\mathrm{GnRH}$ receptor. GnRH agonists act by interfering with the pro-metastatic activity of the growth factor IGF-I.

\section{Introduction}

Prostate cancer is the most frequent malignancy and the second leading cause of male cancer deaths in Western countries (1). In its earlier stages, the disease is androgen-dependent and, therefore, androgen-deprivation therapy represents the firstline treatment for prostate cancer patients (2). After an initial phase of remission, prostate carcinoma almost inevitably progresses towards a condition of hormone-resistance, which is characterized by a high proliferation rate, by a strong metastatic behavior, and by the refractoriness to classical chemotherapy (3). Growth factors, either locally produced or exogenous, the insulin-like growth factor-I (IGF-I) in particular, have been widely shown to be deeply involved in the growth and progression of prostate carcinoma (4-6). Prostate cancer cells produce IGF-I, express IGF-I receptors (IGF-IR) and exhibit a significant responsiveness to the mitogenic activity of IGF-I in vitro (7-10), while IGF-IR inhibition by means of antisense RNA reduces prostate cancer cell proliferation (11). In in vivo studies (performed in SCID mice), the progression of androgen-dependent prostate cancer xenografts (derived from the LAPC-9 and LNCaP cell lines) towards a phase of androgen-independence is associated with increased levels of both IGF-I and IGF-IR (12); similarly, prostate IGF-I mRNA expression was found to increase during prostate cancer progression in TRAMP mice and to be elevated in the accompanying metastases (13). Finally, high serum levels of IGF-I were reported to be associated with an increased risk of prostate cancer in men (14-16); the level of expression of IGF-IR, which is up-regulated in primary prostate cancer, seems to persist in the metastatic disease $(17,18)$. Recently, IGF-I has been reported to increase both the invasive (19) and the migratory (20) behavior of androgen-independent prostate 
cancer cells, indicating that this growth factor might regulate not only the growth but also the progression of prostate cancer towards the highly aggressive metastatic phase.

Gonadotropin-releasing hormone ( $\mathrm{GnRH})$ agonists, through the blockade of the pituitary-testicular axis and the consequent suppression of testosterone secretion, represent the most widely utilized therapy for hormone-responsive prostate carcinoma (2). Moreover, in our $(21,22)$ and in other $(23)$ laboratories it has been demonstrated that GnRH agonists can exert a specific antiproliferative effect on androgen-dependent prostate cancer cells, suggesting that, when utilized for treating patients, these drugs might also exert an additional and more direct antitumor activity. Expression of GnRH receptors and significant antiproliferative effects of $\mathrm{GnRH}$ analogs have also been reported for androgen-independent prostate cancer cells, both in vitro (24) and in vivo when inoculated into nude mice $(23,25,26)$. These observations suggest that $\mathrm{GnRH}$ agonists might exert an anti-tumorigenic action also on hormone-refractory prostate cancer and, therefore, implicate that their clinical application might also be extended to this stage of pathology. In the present study, we investigated whether GnRH agonists might affect the migratory and the invasive properties of androgen-independent prostate cancer cells, in particular of DU 145 cells, and whether they might interfere with the pro-metastatic activity of IGF-I; the molecular mechanisms of this interaction were clarified.

\section{Materials and methods}

Materials. The GnRH agonist Leuprolide (D-Leu ${ }^{6}-\mathrm{Des}_{-} \mathrm{Gly}^{10}{ }_{-}$ GnRH-N-ethylamide) acetate was kindly provided by Takeda (Japan). Human recombinant IGF-I was purchased from Peprotech EC Ltd. (London, UK); mouse anti- $\alpha \mathrm{v} B 3$ antibody was obtained from Chemicon (Temecula, CA) while vitronectin was from Sigma Chemical Co. (St. Louis, MO).

Cell cultures. The cell line DU 145, derived from a brain metastasis of a human hormone-unresponsive prostate carcinoma, and the PC3 cell line, derived from bone metastasis of a human hormone-independent prostate cancer, were obtained from American Type Culture Collection (Rockville, MD). DU 145 cells (passages 60-74) and PC3 cells (passages 20-35) were routinely grown in RPMI-1640 medium supplemented with fetal bovine serum (FBS; Gibco, Paisley, Scotland, UK) (5\% for DU 145 and $10 \%$ for PC3 cells), glutamine $(1 \mathrm{mM})$ and antibiotics (100 IU/ml penicillin $\mathrm{G}$ sodium and $100 \mu \mathrm{g} / \mathrm{ml}$ streptomycin sulphate). Cells were incubated at $37^{\circ} \mathrm{C}$ in a humidified atmosphere of $5 \% \mathrm{CO}_{2} / 95 \%$ air.

Cell proliferation studies. Cell growth studies were performed on exponentially growing cells. DU 145 cells were plated at a density of 500 cells $/ \mathrm{cm}^{2}$ in $100-\mathrm{mm}$ dishes; they were allowed to attach and to start growing for 3 days. The media were then changed and cells were treated daily with Leuprolide $\left(10^{-11}-10^{-6} \mathrm{M}, 500 \mu \mathrm{l}\right)$, as previously described for different GnRH agonists (24). After 7 days of treatment, cells were harvested and counted by hemocytometer. Each experimental group consisted of 6 replicates and each experiment was repeated 3 times. The data were analyzed according to the Bonferroni's test after one-way ANOVA.
Western blot analysis of IGF-IR, IGF-IR phosphorylation and Akt phosphorylation

IGF-IR protein expression. IGF-IR expression was analyzed by Western blotting. DU 154 cells were seeded at a density of $5 \times 10^{5}$ cells in $100-\mathrm{mm}$ dishes in RPMI-1640 medium with $5 \%$ FBS and treated with Leuprolide $\left(10^{-6} \mathrm{M}\right)$ for $24 \mathrm{~h}$. At the end of the treatment, cells were harvested using RIPA buffer (0.05 M Tris.HCl pH 7.7, $0.15 \mathrm{M} \mathrm{NaCl}, 0.8 \%$ SDS, $10 \mathrm{mM}$ EDTA, $100 \mu \mathrm{M} \mathrm{NaVO}_{4}, 50 \mathrm{mM} \mathrm{NaF}, 0.3 \mathrm{mM}$ PMSF, $5 \mathrm{mM}$ iodoacetic acid) containing leupeptin and aprotinin $(1 \mu \mathrm{g} / \mathrm{ml})$. The extracts were centrifuged to remove insoluble material. Protein contents were determined using the BCA method. Equal amounts of proteins $(30 \mu \mathrm{g})$ for each experimental sample were resuspended in sample buffer $(0.5 \mathrm{M}$ Tris- $\mathrm{HCl}$ pH 6.8, glycerol 20\%, SDS 10\%, 2ß-mercaptoethanol $0.2 \%$, blue bromophenol $0.05 \%$ ) and heated at $95^{\circ} \mathrm{C}$ for $5 \mathrm{~min}$. Following separation by $7.5 \%$ SDS-PAGE, proteins were electrotransferred to nitrocellulose, and membranes were then blocked with $3 \%$ BSA. Filters were incubated with the IGF-IR antibody $(1.5 \mu \mathrm{g} / \mathrm{ml}, 2 \mathrm{~h}$ at room temperature) (Chemicon). After repeated washing, membranes were incubated with horseradish peroxidase-conjugated secondary antibodies. Proteins were finally visualized by chemiluminescence (SuperSignal Chemiluminescence Detection System, Pierce Biotechnology Inc., Rockford, IL). A monoclonal antibody against actin (actin, Ab-1 kit, Oncogene Research Products, San Diego, CA) was used to control for equal loading.

Tyrosine phosphorylation of IGF-IR. To study the possible interaction of GnRH agonists with the IGF-I-induced tyrosine phosphorylation of IGF-IR, DU 145 cells were plated at a density of $5 \times 10^{5}$ cells in $100-\mathrm{mm}$ dishes in RPMI-1640 medium supplemented with 5\% FBS. After 3 days, cells were refed with serum-free medium for $24 \mathrm{~h}$ and then pretreated, for 1 or $2 \mathrm{~h}$, with Leuprolide $\left(10^{-6} \mathrm{M}\right)$ before IGF-I stimulation (10 $\mathrm{nM}, 3 \mathrm{~min}$ ), as previously described (10). At the end of the treatment, the experimental medium was removed, the cell layer was rinsed with PBS and cells were then harvested in $1 \mathrm{ml}$ RIPA buffer on ice for $10 \mathrm{~min}$. Cell lysates were centrifuged at $15,000 \mathrm{x}$ g for $20 \mathrm{~min}$; supernatants were immunoprecipitated with $2 \mu \mathrm{g} / 20 \mu \mathrm{l}$ of the monoclonal antibody IGF-IR $\alpha$ (Santa Cruz Biotechnology Inc., Santa Cruz, CA), raised against IGF-IR, for $15 \mathrm{~min}$ in the presence of $10 \mu 1$ rabbit anti-mouse IgG. Protein Sepharose $(75 \mu 1)$ was added at room temperature for $30 \mathrm{~min}$, and samples were then centrifuged at 4,000 x g for $5 \mathrm{~min}$. Precipitated proteins were electrophoresed by SDS-PAGE on a $7.5 \%$ polyacrylamide gel and blotted onto a nitrocellulose filter. Filters were incubated with antiphosphotyrosine monoclonal antibody $\left(\mathrm{IgG} 2 \mathrm{~b}_{\mathrm{k}}\right.$, Upstate Biotechnology, Lake Placid, NY) $(1 \mu \mathrm{g} / \mathrm{ml})$ for $1 \mathrm{~h}$ at room temperature and then with an anti-mouse $\mathrm{IgG}$ at the final concentration of 1:5000. Antibody bound to phosphotyrosine was detected by chemiluminescence.

Akt phosphorylation. DU 145 cells were seeded at a density of $5 \times 10^{5}$ cells in 10-mm dishes in RPMI-1640 medium with $5 \%$ FBS. After 3 days, the medium was changed to serumfree medium and cells were treated with Leuprolide $\left(10^{-6} \mathrm{M}\right)$ for 1 or $2 \mathrm{~h}$, either in the absence or in the presence of IGF-I $(10 \mathrm{nM})$ during the last $30 \mathrm{~min}$ of incubation. At the end of the treatment, the cell layer was rinsed with PBS and cells 
were harvested using RIPA buffer. Western blot analysis was performed as described above. The following primary antibodies were used at a dilution of 1:100 (overnight at $4^{\circ} \mathrm{C}$ ): anti-phospho-Akt (SC 7985-R; Santa Cruz Biotechnology) or anti-Akt (SC 5298, Santa Cruz Biotechnology). All these experiments were repeated 3 times.

Cell migration assays. Cell migration was analyzed by means of haptotactic assays, using a 48-well Boyden's chamber (Neuroprobe, Cabin John, MD) in which the lower surface of the membrane had been precoated with vitronectin $(5 \mu \mathrm{g} /$ $100 \mu \mathrm{l}$ ). After each specific treatment, prostate cancer cells were harvested, resuspended in 5\% FBS additioned medium plus treatments, and cell suspensions $\left(10^{5}\right.$ cells $/ 50 \mu 1$, in culture media plus the specific treatment) were placed in the openbottom wells of the upper compartment of the chamber. Each pair of wells were separated by polyvinylpyrrolidone-free polycarbonate porous membrane ( $8 \mu \mathrm{m}$ pores) precoated with vitronectin. The lower compartment of the chambers was filled with serum-free medium. The chambers were then kept for $4 \mathrm{~h}$ in the cell culture incubator. After that, the cells migrated through the pores and adhered to the underside of the membrane were fixed, stained (Diff-Quick kit, DADE, Dudingen, $\mathrm{CH}$ ) and mounted onto glass slides. For quantitative analysis, six random objective fields of stained cells were counted for each well ( 8 wells/experimental group) and the mean number of migrating cells $/ \mathrm{mm}^{2}$ was calculated.

Preliminary experiments were performed to evaluate the effects of the GnRH agonist on the migratory behavior of prostate cancer cells. To this purpose, subconfluent DU 145 cells, grown in serum-supplemented medium, were treated for 4 days with Leuprolide $\left(10^{-6} \mathrm{M}\right)$ and harvested at the end of the treatment. Haptotactic assays were then performed as described above.

Subsequent experiments were performed to evaluate whether the GnRH agonist might interfere with the promigratory activity of IGF-I. DU 145 cells, cultured in the absence of serum, were treated with Leuprolide $\left(10^{-6} \mathrm{M}\right)$ alone for 4 days, with IGF-I (10 nM) alone for $24 \mathrm{~h}$, or with Leuprolide (4 days) in the presence of IGF-I during the last $24 \mathrm{~h}$. Haptotactic assays were then performed. To confirm the results obtained, similar experiments were performed on PC3 cells.

In each of these assays, triplicate wells were performed, and the assay was repeated 3 times. The data from all migration assays were analyzed according to the Bonferroni's test after one-way ANOVA.

Invasion (Matrigel) assays. Preliminary experiments were performed to verify whether GnRH agonists might affect the invasive properties of androgen-independent prostate cancer cells. To this purpose, subconfluent DU 145 cells were collected by trypsinization, resuspended in complete medium and seeded in $20 \mu 1(150,000$ cells/drop) on the lid of a culture dish. The lid was then placed on a dish filled with 2 $\mathrm{ml}$ of culture medium and incubated at $37^{\circ} \mathrm{C}$ for $48 \mathrm{~h}$. Matrigel solution $(80 \mu 1,2.7 \mathrm{mg} / \mathrm{ml})$ was pipetted onto the bottom of wells of a 24-well culture dish, and left to set at $37^{\circ} \mathrm{C}$. Cell aggregates were gently pipetted and transferred over the cushion and then overlaid with additional $20 \mu 1$
Matrigel. The aggregates into Matrigel were covered with $400 \mu 1$ RPMI-1640 supplemented with 5\% FBS, in the presence or in the absence of Leuprolide $\left(10^{-6} \mathrm{M}\right)$. Aggregates in Matrigel covered with RPMI-1640 without FBS supplementation served as negative controls. The aggregates were then observed daily under a light microscope and at 4 and 9 days phase-contrast pictures of the aggregates were taken. The experiments were repeated 3 times.

To clarify whether Leuprolide might interfere with the proinvasive properties of IGF-I, the Matrigel invasion chamber was utilized, as previously described (27). This method was utilized because it allows a quantitative evaluation of the effect and, therefore, a statistical analysis of the results. Transwell plates equipped with 23.1-mm polycarbonate inserts of pore size $8.0 \mu \mathrm{m}$ (Becton Dickinson, Bedford, MA) were precoated with $0.8 \mathrm{mg} /$ insert solubilized tissue basement membrane (Matrigel) and allowed to dry in a sterile hood overnight. DU 145 cells, cultured in the absence of serum, were treated with Leuprolide $\left(10^{-6} \mathrm{M}\right)$ alone for 4 days, with IGF-I (10 nM) alone for $24 \mathrm{~h}$, or with Leuprolide (4 days) in the presence of IGF-I during the last $24 \mathrm{~h}$. Cells were then harvested by trypsinization, resuspended in their basal medium plus treatment, and seeded into the upper compartment of the invasion chamber at 350,000 cells/well in a volume of $2 \mathrm{ml}$; the lower compartment of the chamber was filled with $20 \%$ FBS-supplemented medium $(3 \mathrm{ml})$. Cells were allowed to invade the Matrigel preparation and to migrate for $72 \mathrm{~h}$ at $37^{\circ} \mathrm{C}$. At the end of the assay, non-invasive cells were removed from the upper surface of the membrane with a cotton swab. Cells that had invaded the Matrigel coating were fixed, stained (Diff-Quick kit, DADE), and counted. In each of these assays, triplicate wells were performed, and the assay was repeated 3 times. The data were analyzed according to the Bonferroni's test after one-way ANOVA.

Scanning electron microscopy. For scanning electron microscopy, DU 145 cells $\left(3 \times 10^{4}\right.$ cells/coverslip) were seeded on vitronectin-coated coverslips and incubated in serum-free medium with IGF-I $(10 \mathrm{nM})$ and Leuprolide $\left(10^{-6} \mathrm{M}\right)$, either alone or in combination, for $30 \mathrm{~min}$. Cells were then washed in PBS for $10 \mathrm{~min}$ and fixed in $2 \%$ glutaraldehyde in $0.1 \mathrm{M}$ cacodylate buffer and then washed in the same buffer. Coverslips were postfixed in aqueous $4 \% \mathrm{OsO}_{4}$ for $20 \mathrm{~min}$, washed in distilled water for $10 \mathrm{~min}$, immersed in aqueous $1 \%$ tannic acid for $20 \mathrm{~min}$ and washed in distilled water for $10 \mathrm{~min}$. This procedure was repeated 3 times at room temperature. Cells were dehydrated in alcohol, immersed in isoamylacetate and dried by the critical-point method. Coverslips were sputtercoated with gold/palladium and observed under a scanning electron microscope (Autoscan Siemens). This experiment was repeated 2 times for 2 different preparations.

Cytoskeletal organization. The effects of IGF-I and the GnRH agonist, either alone or in combination, on the pattern of actin and tubulin distribution were analyzed by immunofluorescence staining. DU 145 cells were grown on 22-mm glass coverslips and treated, in serum-free conditions, with IGF-I $(10 \mathrm{nM})$ and Leuprolide $\left(10^{-6} \mathrm{M}\right)$, either alone or in combination, for $30 \mathrm{~min}$. Cells were then fixed with $3 \%$ paraformaldehyde in $2 \%$ sucrose-PBS for $15 \mathrm{~min}$ and 
permeabilized with $0.5 \%$ Hepes/Triton buffer $(20 \mathrm{mM}$ Hepes, $300 \mathrm{mM}$ sucrose, $50 \mathrm{mM} \mathrm{NaCl}, 3 \mathrm{mM} \mathrm{MgCl}_{2}, 0.5 \%$ Triton $\mathrm{X}-100$ ) for $1 \mathrm{~min}$. For actin visualization cells were stained with tetramethylrhodamine B isothiocyanate (TRITC)phalloidin $(0.4 \mu \mathrm{g} / \mathrm{ml})$ (Sigma Chemical Co.). For tubulin organization, fixed cells were incubated with an unlabeled monoclonal anti-tubulin primary antibody (1:500) (clone DM 1A, Sigma Chemical Co.), followed by TRITC-conjugated goat anti-mouse secondary antibody (Alexa Fluor 488, Molecular Probes, Eugene, OR). Labeled cells were examined under a Zeiss Axiovert 200 microscope with a $63 x / 1.4$ objective lens. Images were acquired using the Metavue program. Each staining was repeated 3 times for 3 different preparations for each group.

Expression of integrin $\alpha v \beta 3$. The effects of IGF-I and Leuprolide, either alone or in combination, on the expression of the $\alpha v \beta 3$ integrin dimer were evaluated by immunofluorescence as well as by biotinylation and immunoprecipitation. This integrin was selected since its expression has been demonstrated to correlate with the aggressiveness and invasiveness of prostate cancer cells (28). The integrin avß3 binds to different proteins of the extracellular matrix, including vitronectin, utilized for the migration assays in the present study (29).

Immunofluorescence analysis. DU 145 cells $\left(3 \times 10^{4}\right.$ cells/ coverslip) were grown on 13-mm glass coverslips and treated, in serum-free conditions, with IGF-I $(10 \mathrm{nM})$ and Leuprolide $\left(10^{-6} \mathrm{M}\right)$, either alone or in combination, for $30 \mathrm{~min}$. Cells were then fixed with paraformaldehyde (as described above) and incubated with an unlabeled anti- $\alpha \mathrm{v} ß 3$ primary antibody (Chemicon), followed by fluorescein isothiocyanate (FITC)conjugated goat anti-mouse secondary antibody (Molecular Probes). Labeled cells were examined as described above for cytoskeletal proteins. Each staining was repeated 3 times for 3 different preparations for each group.

Biotinylation and immunoprecipitation. These experiments were performed as previously described (30). DU 145 cells, grown in serum-free medium, were treated with IGF-I (10 nM) and Leuprolide $\left(10^{-6} \mathrm{M}\right)$, either alone or in combination, for $24 \mathrm{~h}$. The cells were then washed 5 times with Hank's buffer and incubated with $2 \mathrm{ml}$ of Hank's buffer supplemented with $500 \mathrm{mg} / \mathrm{ml}$ sulfoccinimidyl hexanoate-conjugated biotin (NHSLC-Biotin, Pierce Biotechnology Inc.) to label cell surface proteins for $30 \mathrm{~min}$ at $4^{\circ} \mathrm{C}$. Cells were washed 3 times and lysed in $0.5 \mathrm{ml}$ RIPA buffer containing leupeptin and aprotinin $(1 \mu \mathrm{g} / \mathrm{ml})$. The extracts were centrifuged to remove insoluble material. Protein contents were determined using the BCA method. Equal amounts of protein $(0.5 \mathrm{mg})$ for each experimental sample were incubated overnight at $4{ }^{\circ} \mathrm{C}$ with the specific antibodies (mouse anti- $\alpha \mathrm{v} 33,2 \mu 1$; and rabbit anti-mouse, $10 \mu 1$ ). The antibody-integrin complexes were incubated for another $1 \mathrm{~h}$ with protein A-Sepharose (Pharmacia, Uppsala, Sweden), washed 3 times in RIPA buffer and 3 times in purified water. Proteins were separated by $6 \%$ SDS-PAGE, electrotransferred to nitrocellulose, incubated with peroxidase-conjugated streptavidin and visualized by chemiluminescence (SuperSignal Chemiluminescence Detection System, Pierce Biotechnology Inc.). The experiment has been repeated 3 times.

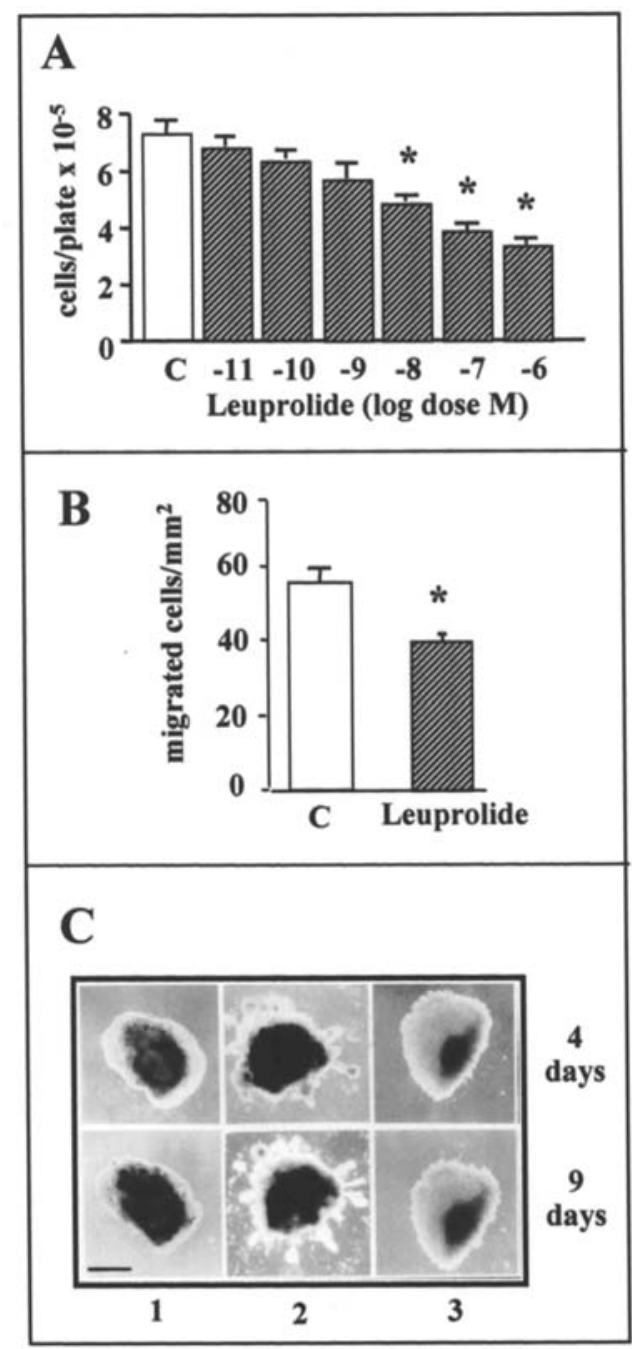

Figure 1. Effects of Leuprolide on DU 145 cell proliferation (A), migration (B), and invasion (C). (A) DU 145 cells, grown in serum-supplemented medium, were treated for 7 days with Leuprolide $\left(10^{-6} \mathrm{M}\right)$. Cells were then harvested and counted by hemocytometer. Data are expressed as mean cell number \pm SE (B) DU 145 cells, grown in serum-supplemented medium, were treated for 4 days with Leuprolide $\left(10^{-6} \mathrm{M}\right)$ and then seeded in the upper compartment of a Boyden's chamber for the haptotactic assay. Data are expressed as mean number of migrated cells $/ \mathrm{mm}^{2} \pm$ SE. (C) DU 145 cells were grown as aggregates in Matrigel covered with serum-supplemented medium containing Leuprolide $\left(10^{-6} \mathrm{M}\right)$. Phase-contrast pictures of the aggregates were taken after 4 and 9 days. Results from 1 out of 3 experiments performed, are reported. Lane 1, aggregates in serum-starved medium; lane 2, aggregates in serum-supplemented medium; lane 3, aggregates in serumsupplemented medium, in the presence of Leuprolide. ${ }^{*} \mathrm{p}<0.05 \mathrm{vs}$. C, controls; scale bar, $400 \mu \mathrm{m}$.

\section{Results}

Leuprolide reduces the migratory and the invasive behavior of DU 145 cells. Preliminary experiments were performed to verify whether Leuprolide might affect the growth of androgen-independent DU 145 prostate cancer cells, as previously reported in our laboratory for other GnRH agonists (24). We were able to confirm that Leuprolide exerts a dosedependent inhibitory effect on DU 145 cell proliferation, being significantly effective in the range of doses $10^{-8}-10^{-6} \mathrm{M}$ (Fig. 1A). On the basis of these results, the dose of $10^{-6} \mathrm{M}$ was selected for all subsequent experiments. This dose corresponds to that of another GnRH agonist (Zoladex) 


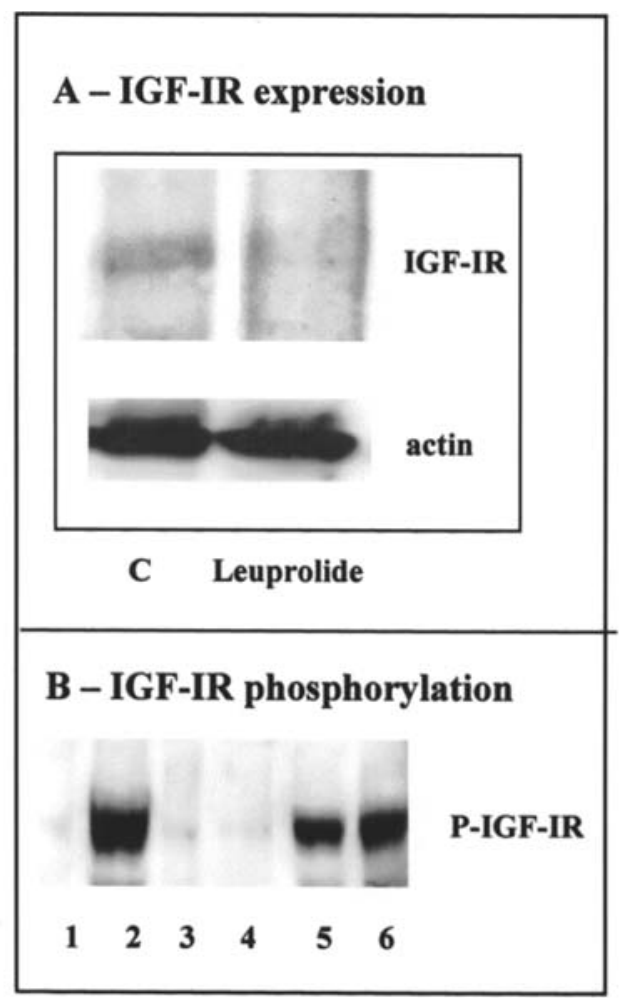

Figure 2. Effects of Leuprolide on IGF-IR expression (A) and IGF-IR tyrosine-phosphorylation (B). (A) DU 145 cells, grown in serum-supplemented medium, were treated with Leuprolide $\left(10^{-6} \mathrm{M}, 24 \mathrm{~h}\right)$. Western blotting of IGF-IR was then performed. Results from 1 out of 3 experiments performed, are reported. Lane 1, controls; lane 2, Leuprolide. (B) DU 145 cells, grown in serum-starved medium, were treated with Leuprolide $\left(10^{-6} \mathrm{M}, 1\right.$ or $\left.2 \mathrm{~h}\right)$ before treatment with IGF-I (10 $\mathrm{nM}, 3 \mathrm{~min})$. Lane 1, untreated controls; lane 2, IGF-I; lane 3, Leuprolide (1 h); lane 4, Leuprolide $(2 \mathrm{~h})$; lane 5 , Leuprolide (1 h) + IGF-I; lane 6, Leuprolide (2 h) + IGF-I. Results from 1 out of 3 experiments performed, are reported.

previously utilized in our laboratory to investigate the mechanisms of the antiproliferative action of GnRH agonists on DU 145 cells (10). These data are also in agreement with those previously reported with Leuprolide on other prostate cancer cell lines, both androgen-dependent and androgenindependent $(23,31)$. Similarly, Sica and coworkers have demonstrated that Leuprolide counteracts the mitogenic activity of EGF on androgen-independent PC3 prostate cancer cells (32).

The effects of Leuprolide on the ability of prostate cancer cells to migrate towards an extracellular matrix ligand (vitronectin, $50 \mu \mathrm{g} / \mathrm{ml}$ ) was investigated by means of a haptotactic assay. We observed that, when DU 145 cells (grown in serum-supplemented medium) were pretreated with Leuprolide for 4 days before being seeded in a vitronectin-coated Boyden's chamber, the number of the cells that migrated towards vitronectin was significantly decreased when compared to control cells (Fig. 1B).

Experiments were then performed to verify whether Leuprolide might also affect the invasive behavior of androgenindependent prostate cancer cells. The effects of Leuprolide were evaluated on the ability of DU 145 cells to invade a matrix of reconstituted basement membrane (Matrigel). DU 145 cells spontaneously form aggregates in Matrigel, when prepared by the hanging-drop technique. Fig. 1C (lane 2)

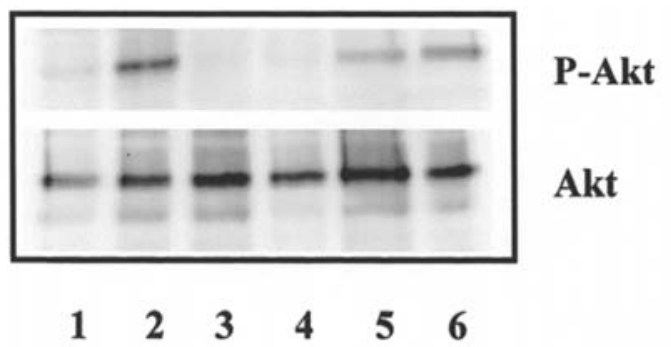

Figure 3. Effects of Leuprolide on the Akt phosphorylation induced by IGF-I. Starved DU 145 cells were treated with Leuprolide $\left(10^{-6} \mathrm{M}\right)$ for 1 or $2 \mathrm{~h}$, either in the absence or in the presence of IGF-I $(10 \mathrm{nM})$ during the last $30 \mathrm{~min}$ of incubation. Lane 1, controls; lane 2, IGF-I (30 min); lane 3, Leuprolide (1 h); lane 4, Leuprolide (2 h); lane 5, Leuprolide (1 h) + IGF-I (30 min); lane 6, Leuprolide (2 h) + IGF-I (30 min). Western blot analysis was then performed using specific antibodies against P-Akt (upper panel) or Akt (lower panel). Results from 1 out of 3 experiments performed, are reported.

shows that DU 145 cells, in serum-supplemented medium, spontaneously leave the aggregates and invade the Matrigel preparation at 4 and 9 days. Treatment of the cells with Leuprolide completely abrogated their migration at the two time intervals considered (Fig. 1C, lane 3).

Leuprolide inhibits the expression and the tyrosinephosphorylation of IGF-IR. We have previously shown that, in DU 145 prostate cancer cells, the GnRH agonist Zoladex reduces the concentration of IGF-IR as measured by radioreceptor assay as well as the IGF-I-induced phosphorylation of the IGF-IR (10). Experiments were now performed to clarify whether similar effects might be elicited by Leuprolide. By Western blot analysis, we demonstrated that treatment of DU 145 cells with Leuprolide $\left(10^{-6} \mathrm{M}\right)$ substantially reduced the expression of the IGF-IR protein (Fig. 2A). To evaluate whether Leuprolide might also interfere with the phosphorylation of the IGF-IR, DU 145 cells were treated with the GnRH agonist for either 1 or $2 \mathrm{~h}$ before being exposed to a 3-min stimulus with IGF-I (10 nM) (10). Fig. 2B (lane 1) shows that the IGF-I receptor is not phosphorylated in DU 145 cells cultured in the absence of serum; this indicates that, in basal conditions, the autocrine IGF-I is not sufficient to activate its own receptors. As expected, IGF-I induced the phosphorylation of IGF-IR (Fig. 2B, lane 2). Leuprolide, when given alone, was completely devoid of effect (Fig. 2B, lanes 3 and 4 vs. lane 1), a result which was expected since in basal conditions IGF-IR was not activated (lane 1). The pretreatment of DU 145 cells with Leuprolide for 1 or $2 \mathrm{~h}$ substantially counteracted the IGF-I-dependent phosphorylation of IGF-IR (Fig. 2B, lanes 5 and 6). These results confirm that Leuprolide interferes with the IGF-I system (receptor levels and phosphorylation), as previously described for the other GnRH agonist Zoladex (10).

Leuprolide inhibits Akt phosphorylation induced by IGF-I. We have recently reported that, in DU 145 cells, IGF-I exerts its pro-migratory activity through the PI3-K/Akt signaling pathway (20). Experiments were performed to verify whether Leuprolide might interfere with the phosphorylation of the Akt kinase induced by IGF-I. DU 145 cells, in serum-free medium, were treated with Leuprolide $\left(10^{-6} \mathrm{M}\right)$ for 1 or $2 \mathrm{~h}$, 

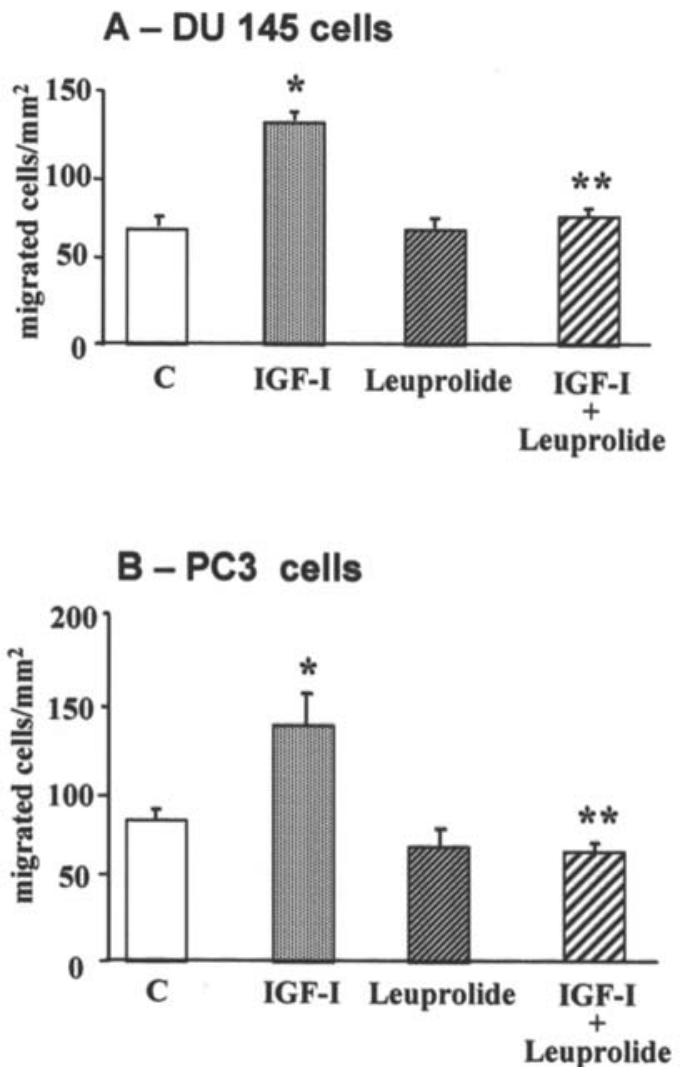

Figure 4. Effects of Leuprolide on the pro-migratory activity of IGF-I. Serum-starved DU 145 (A) and PC3 (B) cells were treated with Leuprolide $\left(10^{-6} \mathrm{M}, 4\right.$ days), either alone or in the presence of IGF-I $(10 \mathrm{nM})$ during the last $24 \mathrm{~h}$. Cells were then harvested, resuspended in their experimental media, and seeded in the upper compartment of a Boyden's chamber for the haptotactic assay. Data are expressed as the mean number of migrated cells $/ \mathrm{mm}^{2} \pm \mathrm{SE} .{ }^{*} \mathrm{p}<0.05$ vs. C, controls $;{ }^{* *} \mathrm{p}<0.05$ vs. IGF-I.

either in the absence or in the presence of IGF-I $(10 \mathrm{nM})$ during the last $30 \mathrm{~min}$ of incubation. The level of Akt phosphorylation was determined by Western blot analysis using a phospho-Akt specific antibody. Fig. 3 (lane 1) shows that, in basal conditions, DU 145 cells express undetectable levels of phosphorylated Akt, confirming that, in the absence of serum, autocrine IGF-I is not sufficient to activate its receptor and the downstream signaling pathway. IGF-I induced a significant increase of phosphorylation of the protein (Fig. 3, lane 2), while Leuprolide was completely devoid of effect when given alone (Fig. 3, lanes 3 and 4 vs. lane 1). Pretreatment of the cells with the GnRH agonist substantially counteracted the IGF-I-dependent phosphorylation of Akt at both time intervals considered (Fig 3, lanes 5 and 6). These effects were specific since the level of expression of the unphosphorylated protein was found to be constant throughout the experiments (Fig. 3).

Leuprolide counteracts the pro-migratory activity of IGF-I. We have recently shown that IGF-I $(10 \mathrm{nM})$ stimulates the migration of DU 145 cells, and that this effect is accompanied by a rearrangement of the cytoskeleton components as well as by a change in cell morphology (as revealed by scanning electron microscopy) and in integrin expression (20). Experiments were then performed to clarify whether Leuprolide $\left(10^{-6} \mathrm{M}\right)$ might decrease the migratory properties of prostate

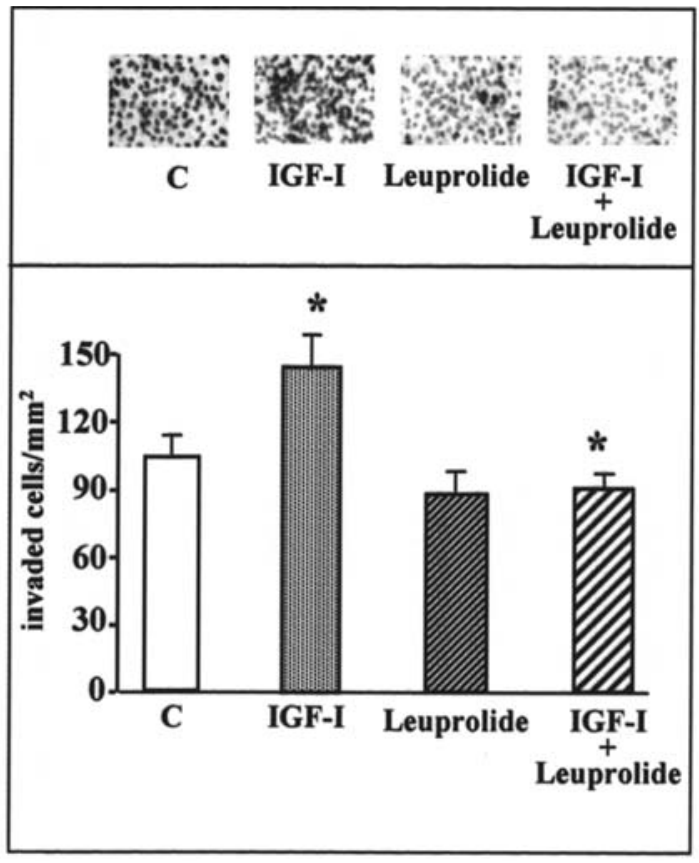

Figure 5. Effects of Leuprolide on the pro-invasive activity of IGF-I. Serumstarved DU 145 cells were treated with Leuprolide $\left(10^{-6} \mathrm{M}, 4\right.$ days), either alone or in the presence of IGF-I $(10 \mathrm{nM})$ during the last $24 \mathrm{~h}$. Cells were then seeded in the upper compartment of a Matrigel invasion chamber. After $72 \mathrm{~h}$, cells that had invaded the Matrigel preparation were fixed, stained and counted. Upper panel, staining of cells migrated through the Matrigel preparation. Lower panel, statistical evaluation of the results obtained. Data are expressed as the mean cell number of invaded cells $/ \mathrm{mm}^{2} \pm \mathrm{SE}$. ${ }^{*} \mathrm{p}<0.05$ vs. C, controls; ${ }^{* *} \mathrm{p}<0.05$ vs. IGF-I.

cancer cells by interfering with the activity of IGF-I. DU 145 cells were treated with Leuprolide for 4 days, either alone or in the presence of IGF-I during the last $24 \mathrm{~h}$ of treatment. Cells were then seeded in the upper compartment of a Boyden's chamber for the haptotactic assay. As expected, IGF-I significantly promoted the migration of DU 145 cells (in serum-free conditions) towards vitronectin. Leuprolide, when given alone, did not affect cell migration; on the other hand, the GnRH agonist significantly prevented the pro-migratory effect of IGF-I (Fig. 4A). Similar results were obtained with the androgen-independent prostate cancer cell line PC3 (Fig. 4B).

Leuprolide counteracts the pro-invasive activity of IGF-I. Grzmil and coworkers (19) have recently reported that IGF-I increases the invasive behavior of androgen-independent PC3 prostate cancer cells. Experiments were performed to verify whether Leuprolide might counteract the pro-invasive activity of IGF-I on DU 145 cells. Using the Matrigel invasion chamber, we found that IGF-I significantly increased the ability of the cells to invade the Matrigel preparation and to migrate towards the lower surface of the inserts. Leuprolide, given alone, had no effect; however, the GnRH agonist completely counteracted the pro-invasive activity of IGF-I (Fig. 5, upper and lower panels).

Effects of Leuprolide on IGF-I-modulated cell morphology, cytoskeleton organization and $\alpha v \beta 3$ integrin expression. The metastatic behavior of tumor cells is usually associated with 

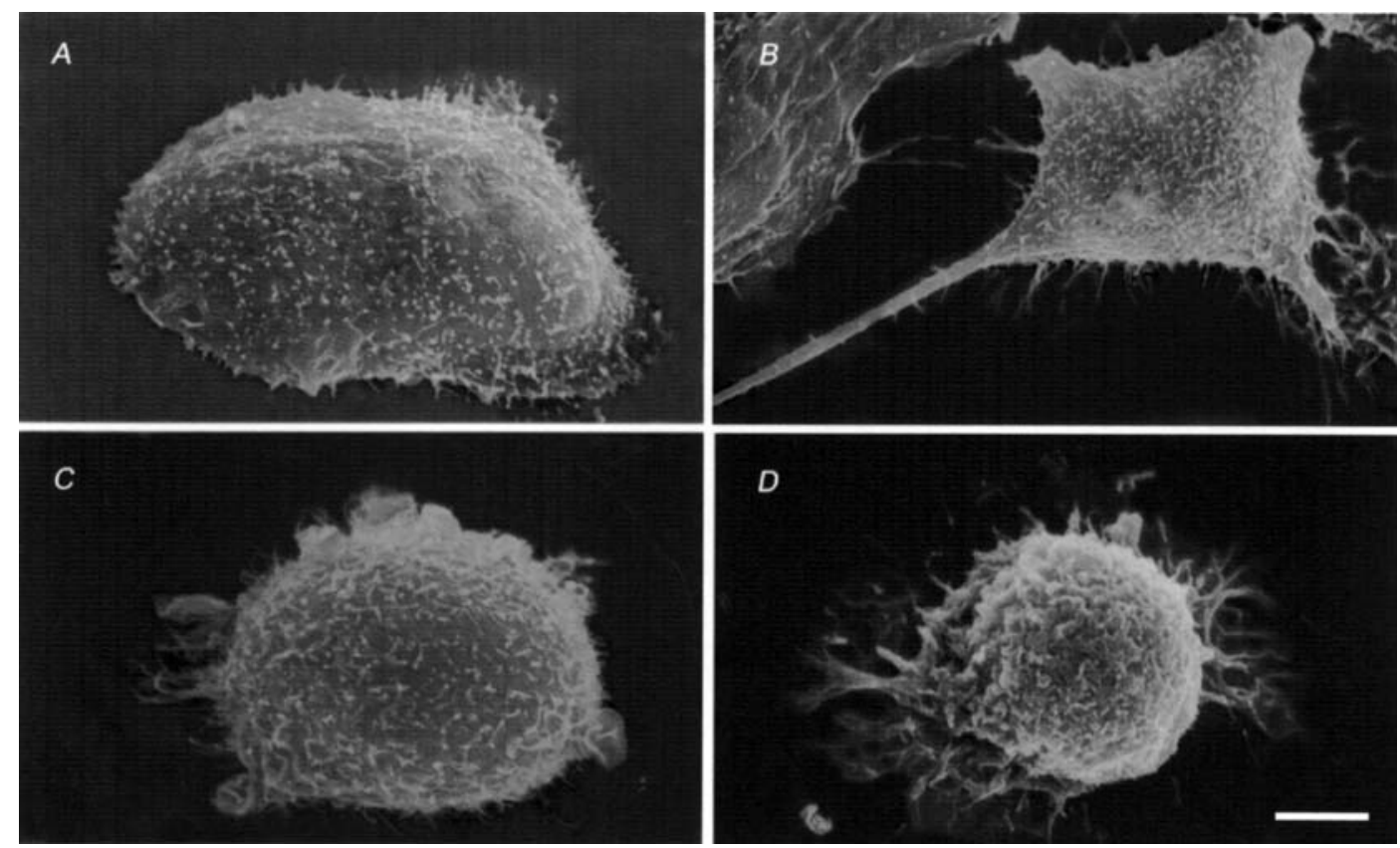

Figure 6. Scanning electron microscopy of serum-starved DU 145 cells, treated with IGF-I ( $10 \mathrm{nM})$ and Leuprolide $\left(10^{-6} \mathrm{M}\right)$, either alone or in combination, for 30 min. (A) Untreated controls; (B) IGF-I; (C) Leuprolide; (D) IGF-I + Leuprolide. Results from 1 out of 2 experiments performed, are reported. The IGF-Iinduced formation and extension of lamellipodia is counteracted by the GnRH agonist. Scale bar, $10 \mu \mathrm{m}$.

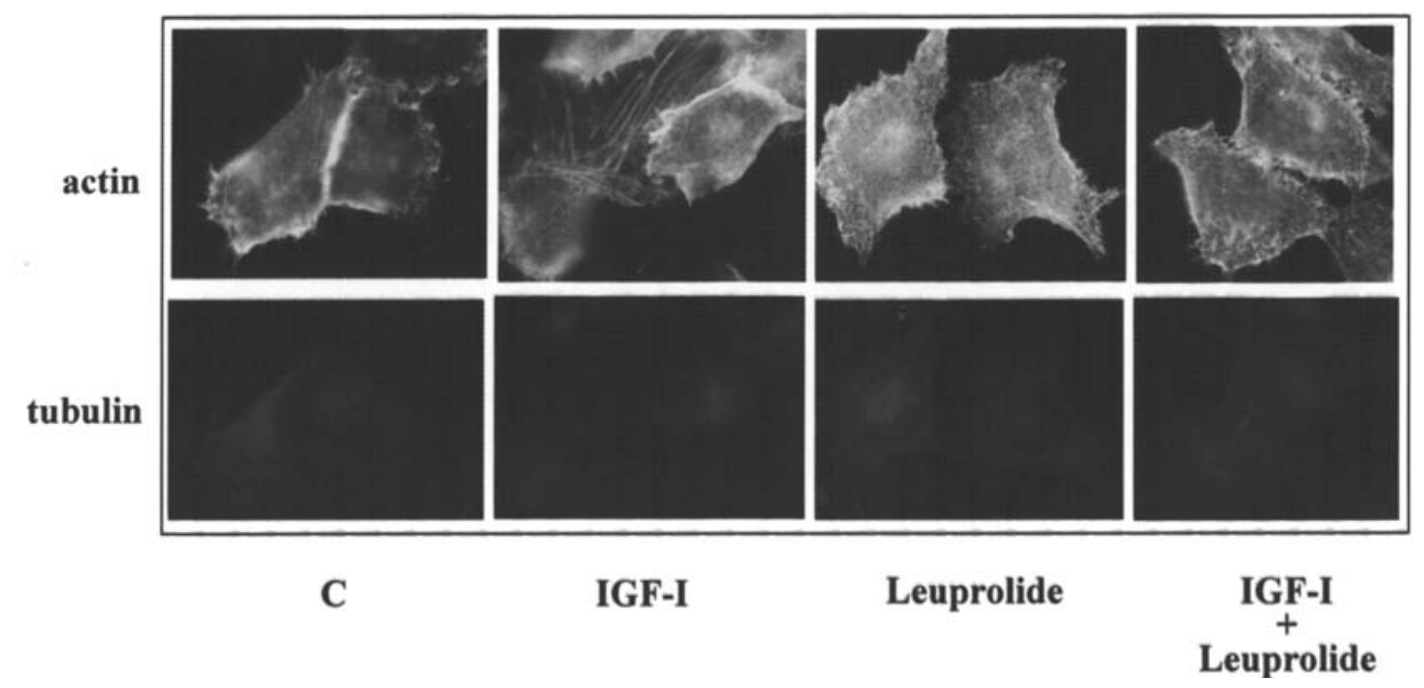

Figure 7. Immunofluorescence staining of F-actin and tubulin showing the effects of IGF-I (10 nM) and Leuprolide (10-6 M), either alone or in combination (for $30 \mathrm{~min}$ ), on cytoskeleton organization of DU 145 cells. Results from 1 out of 3 experiments performed, are reported. IGF-I induces lamellipodia formation and a redistribution of the actin cytoskeleton with increased intensity of the immunofluorescence in peripheral areas below the cell membrane and along the leading edge of lamellipodia. These effects are counteracted by Leuprolide. Neither IGF-I nor Leuprolide, either alone or in combination, affected tubulin immunofluorescence. Scale bar, $16 \mu \mathrm{m}$.

changes in cell morphology, rearrangements of cytoskeletal proteins, as well as alterations of the expression of cell adhesion molecules, such as integrins. Scanning electron microscopy was performed on DU 145 cells treated with IGF-I and Leuprolide, either alone or in combination. Fig. 6B shows the formation of lamellipodia in IGF-I-treated cells, which are not present in control cells; the macrograph also shows that the bodies of IGF-I-treated cells did not adhere to the substratum. Leuprolide, alone, did not modify cell morphology (Fig. 6C); however, the GnRH agonist substantially antagonized the morfological changes induced by IGF-I (Fig. 6D).
Immunofluorescence staining was then performed to clarify whether Leuprolide might affect the IGF-I-induced rearrangement of cytoskeletal components (actin and tubulin) in prostate cancer cells. Fig. 7, confirming our previous observations (20), shows that in DU 145 cells, IGF-I induced a change of cell morphology, with acquisition of lamellipodialike protrusions and a redistribution of the actin cytoskeleton as shown by an increased intensity of the fluorescence in peripheral areas and at the leading edge of the protrusions. Leuprolide, when given alone, did not exert any effect. DU 145 cells treated with the GnRH agonist exhibited a morphology 


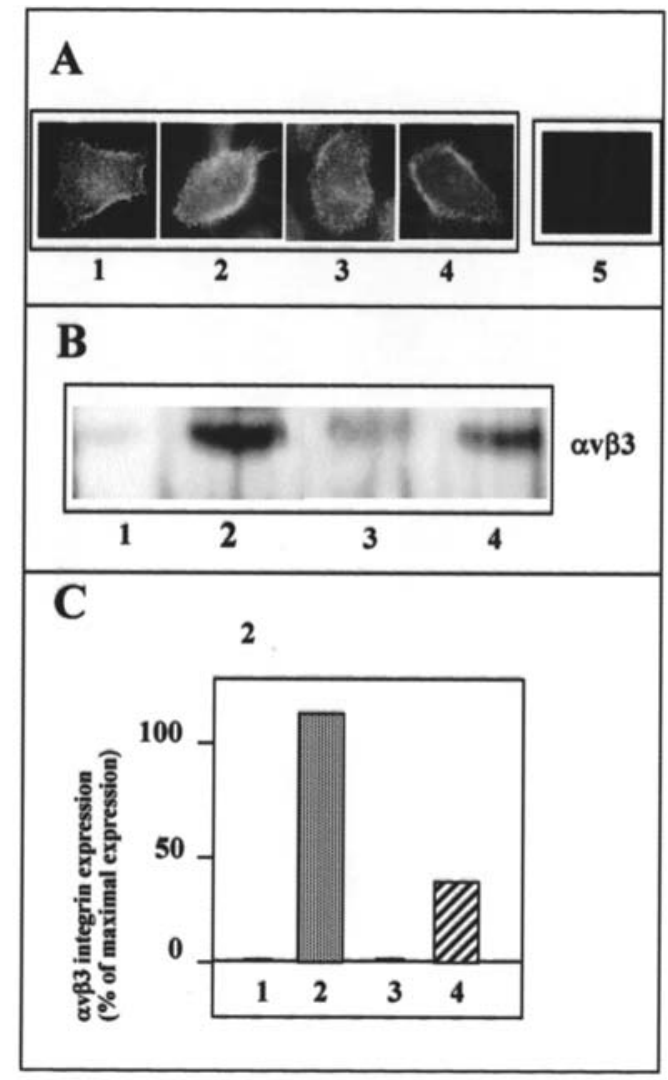

Figure 8. Effects of Leuprolide on the changes of $\alpha \mathrm{v} B 3$ integrin expression induced by IGF-I. Lane 1, controls; lane 2, IGF-I (10 nM); lane 3, Leuprolide $\left(10^{-6} \mathrm{M}\right)$; lane 4 , IGF-I + Leuprolide; lane 5 , negative controls (no primary antibody). (A) Serum-starved DU 145 cells were treated with IGF-I and Leuprolide, either alone or in combination for $30 \mathrm{~min}$. Immunofluorescence analysis of $\alpha \mathrm{v} \beta 3$ was then performed. Scale bar, $16 \mu \mathrm{m}$. (B) Serum-starved DU 145 cells were treated with IGF-I and Leuprolide, either alone or in combination for $24 \mathrm{~h}$. Biotinylation, immunoprecipitation and Western blotting of $\alpha \mathrm{v} B 3$ integrin was then performed. Results from 1 out of 3 experiments performed, are reported. (C) Densitometric analysis of $\alpha \mathrm{v} B 3$ integrin expression reported in (B). The results are expressed as a percentage of the value of IGF-I-induced $\alpha \mathrm{v} B 3$ integrin levels and are the mean $\pm \mathrm{SE}$ of 3 separate experiments.

and an actin cytoskeletal organization similar to that of control cells (Fig. 7). Neither IGF-I nor Leuprolide, given alone or in combination, modified immunofluorescence staining for tubulin in DU 145 cells (Fig. 7).

We have recently reported that, in DU 145 cells, IGF-I increases the expression of $\alpha \mathrm{v} ß 3$ integrin as evaluated both by immunofluorescence and biotinylation/immunoprecipitation followed by Western blot analysis (20). Herein, we studied whether Leuprolide might counteract the action of IGF-I. First of all, Fig. 8A confirms that, in IGF-I-treated cells, the staining of $\alpha v B 3$ fluorescence is increased vs. controls (Fig. 8A, lane 2 vs. lane 1), with a clear localization of the integrin at the cell membrane. Leuprolide, given alone (Fig. 8A, lane 3), did not affect either the intensity of the fluorescence or the cellular localization of $\alpha v B 3$. On the other hand, the effect of IGF-I was clearly abolished by the co-treatment of the cells with the GnRH agonist (Fig. 8A, lane 4 vs. lane 2).

These observations were further confirmed at the protein level. By biotinylation, immunoprecipitation and Western blotting (Fig. 8B) we were able to show that, as expected, $\alpha v ß 3$ protein levels increased after IGF-I treatment (Fig. 8B, lane 2). Leuprolide, given alone, did not affect integrin expression (Fig. 8B, lane 3); however, the GnRH agonist substantially antagonized the effect of the growth factor (Fig. 8B, lane 4).

\section{Discussion}

In this study, we have shown that the GnRH agonist Leuprolide reduces both the motility and the invasive behavior of androgen-independent prostate cancer cells. To investigate the possible mechanisms of this anti-metastatic action, we first analyzed whether the GnRH agonist might interefere with the activity of the growth factor IGF-I.

In a recent study, we have shown that IGF-I, through the activation of its specific receptor, exerts a significant promigratory activity on androgen-independent prostate cancer cells (DU 145 and PC3); this effect is mediated by the PI3-K/ Akt signaling pathway (20). Moreover, the pro-migratory activity of IGF-I on DU 145 cells is accompanied by a change in cell morphology (induction of lamellipodia) and in actin cytoskeleton organization (20). IGF-I also acts by increasing the expression/activity of the $\alpha \mathrm{v} \beta 3$ integrin dimer (20), an integrin whose expression has previously been demonstrated to correlate with the aggressiveness and invasiveness of prostate cancer cells (28). The observation that IGF-I promotes the metastatic ability of androgen-independent prostate cancer cells is also underlined by Grzmil and coworkers (19) who have shown that IGF-I increases the invasive activity of PC3 cells.

In the present study, we have demonstrated that, in androgen-independent prostate cancer cells, Leuprolide reduces both the expression and the tyrosine phosphorylation of the IGF-I receptor, as previously shown for other GnRH agonists (10); in these cells, Leuprolide also substantially counteracts the IGF-I-induced phosphorylation of the Akt kinase. These data indicate that, in androgen-independent prostate cancer cells, GnRH agonists interfere with the IGF-I system in terms of both IGF-IR expression and activation. Moreover, we demonstrated that Leuprolide neutralizes the pro-migratory and pro-invasive activity of IGF-I by counteracting the effects of this growth factor on cell morphology, actin cytoskeleton organization and $\alpha \mathrm{v} \beta 3$ integrin expression. It is clear from these results that, in DU 145 cells, GnRH agonists may exert their anti-metastatic activity by eliciting both very early events (IGF-IR phosphorylation, Akt phosphorylation, changes of cell morphology, actin/integrin intracellular redistribution) as well as events that require a longer time before appearing (IGF-IR expression, changes in cell motility/invasion, integrin expression). Since the appearance of the early events elicited by Leuprolide only needs changes in the activity of specific pre-existing proteins, we believe that these events are likely mediated by the activation of the Gai-cAMP signal transduction pathway which also facilitates the translocation to the plasma membrane of a protein phosphatase (33-35). On the other hand, a longer time, and consequently a prolonged treatment with the GnRH agonist, might be required in order to induce more complex events, such as proliferation/migration/ invasion, which obviously require de novo protein synthesis. 
In line with the data reported herein, Gnanapragasam and coworkers (36) have shown that the GnRH agonist Buserelin substantially counteracts the pro-invasive effects of the fibroblast growth factor (FGF) on DU 145 cells. Moreover, Dondi and coworkers (31) have reported that Leuprolide exerts an anti-metastatic activity on androgen-independent prostate cancer cells, through the inhibition of the urokinse plasminogen activator (uPA) system.

However, the results seem to diverge, at least partially, from those recently published by Enomoto et al (37). These authors have studied the effects of GnRH and of the second form of GnRH recently found in mammals (GnRH-II) (3841 ) on the motility of two prostate cancer cell lines (TSU-Pr1 and DU 145), by utilizing a modified Boyden's chamber. They have reported that GnRH does not affect the migration of either TSU-Pr1 or DU 145 cells when the peptide is placed in the lower compartment of the chamber as a chemo-attractant. On the other hand, the addition of GnRH to the cells in the upper compartment appears able to modulate cell migration (inhibiting it in DU 145 cells, and, on the contrary, being stimulatory in TSU-Pr1 cells) when the conditioned medium of the same cell line is placed in the lower compartment. Similar results have been reported by these authors for GnRHII. The reasons for the discrepancy between the data by Enomoto and coworkers (37) and those reported in the present study probably reside in the many differences encountered in the methodology applied. First of all, the migration assay, based on the Boyden's chamber technique, has been developed in different experimental conditions. In our studies, the ability of the GnRH agonist to affect cell motility has been evaluated by means of a haptotactic assay, using vitronectin as the chemoattractant. Enomoto and coworkers, in their first series of experiments, used an assay where GnRH and GnRH-II, placed in the lower compartment of the chamber, would act as the chemoattractant. In a subsequent experiment, GnRHs were able to affect the motility of the cells (in opposite fashions) when added in the upper compartment of the chamber and when the conditioned media of the same cells were placed as chemoattractants in the lower compartment. A more important difference resides in the fact that Enomoto and coworkers used native GnRHs rather than GnRH analogs. It is known that the half-life of GnRHs is very short (in the range of minutes) and, consequently, it is expected that very little, if any, GnRHs might be present at the end of the experiment (hours). This obviously does not happen with GnRH analogs. Finally, we have shown that Leuprolide decreases the migration of both DU 145 and PC3 cell lines, which are well studied and are usually considered the best example of androgen-independent cells. On the other hand, Enomoto and coworkers, while confirming an anti-migratory activity of GnRHs on DU 145 cells which is comparable to that presented herein, reported an opposite effect of the peptides on the TSU-Pr1 cell line, which is another experimental model of androgen-independent prostate carcinoma. These authors speculate that the opposite effects of GnRH on the migration of TSU-Pr1 and DU 145 cells are linked to different types of GnRH receptors which might be present on the two cell lines.

In support to our observations, an anti-metastatic activity for $\mathrm{GnRH}$ agonists has been previously reported also for cancers not related to the reproductive system, such as melanoma (42) and epidermoid carcinoma (43), expressing the GnRH receptor. Moreover, GnRH agonists have been consistently shown to be inhibitory on the proliferation of both hormone-related (breast, endometrium, ovary, prostate) $(34,44-49)$ and hormone-unrelated cancer cells $(42,43)$.

The results shown in the present study, such as those by Gnanapragasam and coworkers (36) indicate that GnRH agonists inhibit the metastatic behavior of prostate cancer cells, at least partially, by interfering with the stimulatory action of growth factors. This conclusion also seems to be supported by Yates and coworkers (50), who reported that the GnRH antagonist Cetrorelix reduces the invasive profile of DU 145 cells engineered to overexpress the epidermal growth factor (EGF) receptor. To this purpose, it must be noted that Cetrorelix behaves as an antagonist at the GnRH receptor on pituitary gonadotropes and as an agonist at the same receptor on cancer cells (51-55).

In a previous study, we have shown that GnRH agonists reduce the growth of DU 145 cells by interfering with the mitogenic activity of the IGF-I system; these compounds act, as reported also in this study, by decreasing the concentration of IGF-I binding sites and by counteracting the tyrosine phosphorylation of these receptors induced by IGF-I (10). These observations, taken together with those presented in this study, indicate that, in androgen-independent prostate cancer cells, GnRH agonists might exert a direct antitumor effect (by reducing both the proliferation and the metastatic behavior of the cells) acting, at least partially, by interfering with the activity of the growth factor IGF-I.

As it is very well known, GnRH agonists are widely and successfully used for the treatment of androgen-dependent prostate carcinoma, on the basis of their ability to suppress the function of the pituitary-gonadal axis (2). The present data strongly suggest that these compounds might be considered also as a possible treatment for the most advanced hormoneresistant prostate carcinoma. Also the recent study by Gnanapragasam et al (36), based on clinical observations, supports this hypothesis. In this study, prostate cancer patients expressing high levels of GnRH receptors in the tumoral tissue, were divided into two groups of treatments: GnRH agonist therapy or surgical castration. The authors report that patients who received GnRH agonists had a longer survival than those who were surgically castrated. The authors propose an interesting hypothesis to explain the direct antitumor activity exerted by $\mathrm{GnRH}$ agonists in prostate cancer. According to this hypothesis, the direct antitumor activity of these compounds might not be apparent in the androgen-dependent phase of the pathology since this is masqued by the indirect inhibition induced by the suppression of testosterone secretion. On the contrary, in androgen-independent prostate cancers which express high levels of GnRH receptors, GnRH agonists may exert their 'pure' direct anti-mitogenic and anti-metastatic activities which will be associated with a prolongation of the life of the patient.

A general practical conclusion which may be derived from the present study is that the level of expression of $\mathrm{GnRH}$ receptors in prostate cancers might represent a novel molecular 
marker able to help in deciding whether the treatment with $\mathrm{GnRH}$ analogs might be useful also in the more advanced phase of pathology.

\section{Acknowledgements}

We are indebted to Dr Luciano Martini and Dr Marcella Motta for their valuable suggestions and advice. This work was supported by COFIN/MIUR and by Center for Endocrinological Oncology. We are grateful to Takeda (Japan) for kindly providing the GnRH agonist Leuprolide.

\section{References}

1. Jemal A, Murray T, Ward E, Samuels A, Tiwari RC, Ghafoor A, Feuer EJ and Thun MJ: Cancer statistics, 2005. CA Cancer J Clin 55: 10-30, 2005.

2. Labrie F, Belanger A, Luu-The V, Labrie C, Simard J, Cusan L, Gomez J and Candas B: Gonadotropin-Releasing Hormone agonists in the treatment of prostate cancer. Endocr Rev 26: 361-379, 2005.

3. Lee ECY and Tenniswood MPR: Emergence of metastatic hormone-refractory disease in prostate cancer after antiandrogen therapy. J Cell Biochem 91: 662-670, 2004.

4. Djavan B, Waldert M, Seitz C and Marberger M: Insulin-like growth factors and prostate cancer. World J Urol 19: 225-231, 2001 .

5. Renehan AG, Zwahlen M, Minder C, O'Dwyer ST, Shalet SM and Egger M: Insulin-like growth factor (IGF)-I, IGF binding protein-3, and cancer risk: systematic review and meta-regression analysis. Lancet 363: 1346-1353, 2004.

6. Papatsoris AG, Karamouzis MV and Papavassiliou AG: Novel insights into the implication of the IGF-I network in prostate cancer. Trend Mol Med 11: 52-55, 2005.

7. Iwamura M, Sluss PM, Casamento JB and Cockett ATK: Insulin-like growth factor I: action and receptor characterization in human prostate cancer cell lines. Prostate 22: 243-252, 1993.

8. Connolly JM and Rose DP: Regulation of DU145 human prostate cancer cell proliferation by insulin-like growth factors and its interaction with the epidermal growth factor autocrine loop. Prostate 24: 167-175, 1994.

9. Kimura G, Kasuya J, Giannini S, Honda Y, Mohan S, Kawachi M, Akimoto M and Fujita-Yamaguchi Y: Insulin-like growth factor (IGF) system components in human prostatic cancer cell lines: LNCaP, DU145, and PC-3 cells. Int J Urol 3: 39-46, 1996.

10. Montagnani Marelli M, Moretti RM, Dondi D, Motta M and Limonta P: Luteinizing Hormone-Releasing Hormone agonists interfere with the mitogenic activity of the insulin-like growth factor system in androgen-independent prostate cancer cells. Endocrinology 140: 329-334, 1999.

11. Burfeind P, Chernicky CL, Rininsland F and Ilan J: Antisense RNA to the type I insulin-like growth factor receptor suppresses tumor growth and prevents invasion by rat prostate cancer cells in vivo. Proc Natl Acad Sci USA 93: 7263-7268, 1996.

12. Nickerson T, Chang F, Lorimer D, Smeekens SP, Sawyers C and Pollak M: In vivo progression of LAPC-9 and LNCaP prostate cancer models to androgen independence is associated with increased expression of insulin-like growth factor I (IGF-I) and IGF-I receptor (IGF-IR). Cancer Res 61: 6276-6280, 2001.

13. Kaplan PJ, Mohan S, Cohen P, Foster BA and Greenberg NM: The insulin-like growth factor axis and prostate cancer: lessons from the transgenic adenocarcinoma of mouse prostate (TRAMP) model. Cancer Res 59: 2203-2209, 1999.

14. Chan JM, Stampfer MK, Giovannucci E, Gann PH, Ma J, Wilkinson P, Hennekens CH and Pollak M: Plasma insulin-like growth factor-I and prostate cancer risk: a prospective study. Science 279: 563-566, 1998.

15. Stattin P, Bylund A, Rinaldi S, Biessy C, Dechaud H, Stenman UH, Egevad L, Riboli E, Hallmans G and Kaaks R: Plasma insulin-like growth factor-I, insulin-like growth factorbinding proteins, and prostate cancer risk: a prospective study. J Natl Cancer Inst 92: 1910-1917, 2000.

16. Nam RK, Trachtenberg J, Jewett MA, Toi A, Evans A, Emami M, Narod SA and Pollak M: Serum insulin-like growth factor-I levels and prostatic intraepithelial neoplasia: a clue to the relationship between IGF-I physiology and prostate cancer risk. Cancer Epidemiol Biomarkers Prev 14: 1270-1273, 2005.
17. Hellawell GO, Turner GDH, Davies DR, Poulsom R, Brewster SF and Macaulay VM: Expression of the type 1 insulin-like growth factor receptor is up-regulated in primary prostate cancer and commonly persists in metastatic disease. Cancer Res 62: 2942-2950, 2002.

18. Krueckl SL, Sikes RA, Edlund NM, Bell RH, Hurtado-Coll A, Fazli L, Gleave ME and Cox ME: Increased insulin-like growth factor I receptor expression and signaling are components of androgen-independent progression in a lineage-derived prostate cancer progression model. Cancer Res 64: 8620-8629, 2004.

19. Grzmil M, Hemmerlein B, Thelen P, Schweyer S and Burfeind P: Blockade of the type I IGF receptor expression in human prostate cancer cells inhibits proliferation and invasion, upregulates IGF binding protein-3, and suppresses MMP-2 expression. J Pathol 202: 50-59, 2004.

20. Montagnani Marelli M, Moretti RM, Procacci P, Motta M and Limonta P: Insulin-like Growth Factor-I promotes migration in human androgen-independent prostate cancer cells via $\alpha \mathrm{v} B 3$ integrin and PI3-K/Akt signaling. Int J Oncol 28: 723-730, 2006.

21. Limonta P, Dondi D, Moretti RM, Maggi R and Motta M: Antiproliferative effects of luteinizing hormone-releasing hormone agonists on the human prostatic cancer cell line LNCaP. J Clin Endocrinol Metab 75: 207-212, 1992.

22. Limonta P, Dondi D, Moretti RM, Fermo D, Garattini E and Motta M: Expression of luteinizing hormone-releasing hormone mRNA in the human prostatic cancer cell line LNCaP. J Clin Endocrinol Metab 76: 797-800, 1993.

23. Loop SM, Gorder CA, Lewis SM, Saiers JH, Drivdahl RH and Ostenson RC: Growth inhibition of human prostate tumor cells by an agonist of gonadotrophin-releasing hormone. Prostate 26 : 179-188, 1995.

24. Dondi D, Limonta P, Moretti RM, Montagnani Marelli M, Garattini E and Motta M: Antiproliferative effects of luteinizing hormone-releasing hormone (LHRH) agonists on human androgen-independent prostate cancer cell line DU 145: evidence for an autocrine-inhibitory GnRH loop. Cancer Res 54: 4091-4095, 1994.

25. Pinski J, Reile H, Halmos G, Groot K and Schally AV: Inhibitory effects of analogs of luteinizing hormone-releasing hormone on the growth of the androgen-independent Dunning R-3327-AT-1 rat prostate cancer. Int J Cancer 59: 51-55, 1994.

26. Dondi D, Moretti RM, Montagnani Marelli M, Pratesi G, Polizzi D, Milani M, Motta M and Limonta P: Growth inhibitory effects of luteinizing hormone-releasing hormone $(\mathrm{GnRH})$ agonists on xenografts of the DU 145 human androgenindependent prostate cancer cell line in nude mice. Int J Cancer 76: 506-511, 1998.

27. Jones HE, Goddard L, Gtee JMW, Hiscox S, Rubini M, Barrow D, Knowlden JM, Williams S, Wakeling AE and Nicholson RI: Insulin-like growth factor-I receptor signalling and acquired resistance to gefitinib (ZD1839; Iressa) in human breast and prostate cancer cells. Endocr-Rel Cancer 11: 793-814, 2004.

28. Zheng D-Q, Woorward AS, Fornaro M, Tallini G and Languino LR: Prostatic carcinoma cell migration via $\alpha \mathrm{v} B 3$ integrin is modulated by a focal adhesion kinase pathway. Cancer Res 59: 1655-1664, 1999.

29. Hood JD and Cheresh DA: Role of integrins in cell invasion and migration. Nat Rev Cancer 21: 91-100, 2002.

30. Moretti RM, Montagnani Marelli M, Motta M and Limonta P: Role of the orphan nuclear receptor ROR $\alpha$ in the control of the metastatic behavior of androgen-independent prostate cancer cells. Oncol Rep 9: 1139-1143, 2002.

31. Dondi D, Festuccia C, Piccolella M, Bologna M and Motta M: GnRH agonists and antagonists decrease the metastatic progression of human prostate cancer cell lines by inhibiting the plasminogen activator system. Oncol Rep 15: 393-400, 2006.

32. Sica G, Iacopino F, Settesoldi D and Zelano G: Effect of leuprorelin acetate on cell growth and prostate-specific antigen gene expression in human prostatic cancer cells. Eur Urol 35, (Suppl 1): 2-8, 1999.

33. Limonta P, Moretti RM, Montagnani Marelli M, Dondi D, Parenti $\mathrm{M}$ and Motta $\mathrm{M}$ : The luteinizing hormone-releasing hormone receptor in human prostate cancer cells: messenger ribonucleic acid expression, molecular size, and signal transduction pathway. Endocrinology 140: 5250-5256, 1999.

34. Imai A and Tamaya T: GnRH receptor and apoptotic signalling. Vitam Horm 59: 1-33, 2000. 
35. Grundker C, Volker P, Gunthert AR and Emons G: Antiproliferative signaling of LHRH in human endometrial and ovarian cancer cells through G-protein ai-mediated activation of phopshotyrosine-phosphatase. Endocrinology 142: 2369-2380, 2001.

36. Gnanapragasam VJ, Darby S, Khan MM, Lock WG, Robson CN and Leung HY: Evidence that prostate gonadotropin-releasing hormone receptors mediate an anti-tumorigenic response to analogue therapy in hormone refractory prostate cancer. J Pathol 206: 205-213, 2005.

37. Enomoto M, Utsumi M and Park MK: Gonadotropin-releasing hormone induces actiin cytoskeleton remodeling and affects cell migration in a cell-type-specific manner in TSU-Pr1 and DU145 cells. Endocrinology 147: 530-542, 2006.

38. Chen A, Yahalom D, Ben-Aroya N, Kaganovsky E, Okon E and Koch Y: A second isoform of gonadotropin-releasing hormone is present in the brain of human and rodents. FEBS Lett 435: 199-203, 1998.

39. White RB, Eisen JA, Kasten TL and Fernald RD: Second gene for gonadotropin-releasing hormone in humans. Proc Natl Acad Sci USA 95: 305-309, 1998.

40. Neill JD: Minireview: GnRH and GnRH receptor genes in the human genome. Endocrinology 143: 737-743, 2002.

41. Millar RP: GnRH II and type II GnRH receptors. Trends Endocrinol Metab 14: 35-43, 2003.

42. Moretti RM, Montagnani Marelli M, van Groeninghen JC and Limonta P: Locally expressed GnRH receptors mediate the oncostatic and antimetastatic activity of GnRH agonists on melanoma cells. J Clin Endocrinol Metab 87: 3791-3797, 2002.

43. Huang Y, Hwang J, Lee L, Liebow C, Lee PH, Ke F, Lo F, Schally AV and Lee M: Inhibitory effects of a luteinizing hormone-releasing hormone agonist on basal and epidermal growth factor-induced cell proliferation and metastasisassociated properties in human epidermoid carcinoma A431 cells. Int J Cancer 99: 505-513, 2002.

44. Grundker C, Gunthert AR, Westphalen S and Emons G: Biology of the gonadotropin-releasing hormone system in gynecological cancers. Eur J Endocrinol 146: 1-14, 2002.

45. Grundker $\mathrm{C}$ and Emons G: Role fo gonadotropin-releasing hormone $(\mathrm{GnRH})$ in ovarian cancer. Reprod Biol Endocrinol 1: 65-71, 2003.

46. Limonta P, Moretti RM, Montagnani Marelli M and Motta M: The biology of gonadotropin-releasing hormone: role in the control of tumor growth and progression in humans. Front Neuroendocrinol 24: 279-295, 2003.
47. Sugiyama M, Imai A, Takahashi S, Hirano S, Furui T and Tamaya T: Advanced indications for gonadotropin-releasing hormone $(\mathrm{GnRH})$ analogues in gynecological oncology. Int $\mathbf{J}$ Oncol 23: 445-452, 2003 .

48. Harrison GS, Wierman ME, Nett TM and Glode LM: Gonadotropin-releasing hormone and its receptor in normal and malignant cells. Endocr-Rel Cancer 11: 725-748, 2004.

49. Montagnani Marelli M, Moretti RM, Januszkiewicz-Caulier J, Motta M and Limonta P: Gonadotropin-releasing hormone $(\mathrm{GnRH})$ receptors in tumors: a new rationale for the therapeutical application of $\mathrm{GnRH}$ analogs in cancer patients? Current Cancer Drug Targets 6: 89-105, 2006.

50. Yates C, Wells A and Turner T: Luteinising hormone-releasing hormone analogue reverses the cell adhesion profile of EGFR overexpressing DU-145 human prostate carcinoma subline. Br J Cancer 92: 366-375, 2005.

51. Jungwirth A, Pinski J, Galvan G, Halmos G, Szepeshazi K, Cai RZ, Groot K, Vadillo-Buenfil M and Schally AV: Inhibition of growth of androgen-independent DU-145 prostate cancer in vivo by luteinising hormone-releasing hormone antagonist Cetrorelix and bombesin antagonists RC-3940-II and RC-3950-II. Eur J Cancer 33: 1141-1148, 1997.

52. Lamharzi N, Schally AV and Koppan M: Luteinizing hormonereleasing hormone (LH-RH) antagonist Cetrorelix inhibits growth of DU-145 human androgen-independent prostate carcinoma in nude mice and suppresses the levels and mRNA expression of IGF-II in tumors. Regul Pept 77: 185-192, 1998.

53. Tang X, Yano T, Osuga Y, Matsumi H, Yano N, Xu J, Wada O, Koga K, Kugu K, Tsutsumi O, Schally AV and Taketani Y: Cellular mechanisms of growth inhibition of human epithelial ovarian cancer cell line by LH-releasing hormone antagonist Cetrorelix. J Clin Endocrinol Metab 87: 3721-3727, 2002.

54. Emons G, Grundker C, Gunthert AR, Westphalen S, Kavanagh J and Verschraegen $\mathrm{C}$ : GnRH antagonists in the treatment of gynecological and breast cancers. Endocr-Rel Cancer 10: 291-299, 2003.

55. Grundker C, Schlotawa L, Viereck V, Eicke N, Horst A, Kairies B and Emons G: Antiproliferative effects of the GnRH antagonist cetrorelix and of GnRH-II on human endometrial and ovarian cancer cells are not mediated through the GnRH type I receptor. Eur J Endocrinol 151: 141-149, 2004. 